Synthesis, part of a Special Feature on Ecosystem Services, Governance, and Stakeholder Participation

\title{
From Polluter Pays to Provider Gets: Distribution of Rights and Costs under Payments for Ecosystem Services
}

\author{
Volker Mauerhofer $^{1}$, Klaus Hubacek ${ }^{2}$ and Alastor Coleby ${ }^{3}$
}

\begin{abstract}
Should society have the right to freely available clean air and water, or should people be required to pay for these as commodities just as they do for many other goods or services that they consume? With this question and further questions on environmental governance in mind, we reviewed the paradigm shift in natural resource management from the polluter pays principle (PPP), which focuses on polluters and enforcement of thresholds, to the principle of payments for ecosystem services (PES), which emphasizes provider-based economic approaches. Given that there are conflicts of interest over natural resources and ecosystem services (ESs), these conflicts could be resolved through rights and/or cost assignments via third-party intervention, i.e., by the "state," or through private compensation beyond initial regulation and state-initiated assignments of cost. Our analysis includes an in-depth literature review and a description of existing policies on ESs. We also examine the so-called Coase theorem based on a "neutral" situation where no rights or costs are distributed in advance. This theorem provides room for the PPP approaches and the provider-gets approaches. Both of these approaches should ensure, given certain assumptions, an economically efficient allocation of resources; however, they still ignore two indispensable issues, namely, the ecologically sustainable scale and inherent qualities of ecosystems and the distributional effects. With regard to the relationship between these two sets of approaches and their respective relationship to the legal framework, PES programs can evolve instead of PPP where no regulations are in place, existing regulations are deemed to be insufficiently formulated, or regulations are not enforced at all. We also further address some critical issues that can arise when PES programs evolve instead of PPP in practice, such as the general necessity of PES to coexist with basic rights and legal obligations, inappropriate lexicographic claims from providers of ESs, alongside claims for potential damages and the relationship of PES with the intrinsic motivation of service providers. Critically, insufficient attention has been paid to the fact that by replacing the earlier PPP doctrine with the "provider-gets" principle, rights are redistributed from the public to the service provider with important distributional implications for society. Therefore, the replacement of PPP with PES includes obstacles as well as opportunities, in particular for the relationship between rich and poor, and developing and developed countries.
\end{abstract}

Key Words: ecosystem services; efficient allocation; environmental principle; fair distribution; human right; property rights; sustainable scale

\section{INTRODUCTION}

The ecosystem service (ES) framework seeks to integrate the biophysical and social dimensions of environmental protection to address the environmental crises that will likely peak in the 21st century (Daily et al. 2000). This widely accepted framework provides the nexus between ecology and economics and has been seen as a paradigm shift in the way people think about the natural environment (Turner and Daily 2008). Increasingly, ecosystems are being seen as capital assets, with the potential to generate a stream of vital lifesupport services and thus require careful evaluation and investment to align economic incentives with the need for conservation of natural resources. From this paradigm, the payments for ecosystem services (PES) concept is evolving and attracting considerable attention among environmental scientists and managers, and it has been extensively and critically debated (see, e.g., Gobbi 2000, Pagiola et al. 2004, Farley 2008, Spash 2008, Redford and Adams 2009, Norgaard 2010, Vatn 2010, Kinzig et al. 2011).
PES programs are generally defined as voluntary transactions in which a well-defined ES is "bought" by at least one service user from at least one service provider but in which only the provider can actually secure service provision, aka conditionality (Wunder 2005, Engel et al. 2008). In comparison, the polluter pays principle (PPP) is where damage to an ES should be prevented or compensated for by the person who is either likely to cause damage to an ES or has actually caused damage (Førsund 1975, Baldock 1992, Seymour et al. 1992). By contrast, the PES concept shifts the financial burden to the recipient of a certain ES. Since their emergence, PES programs have been categorized in a number of ways: The payments themselves have included user-financed PES programs in which funding comes either from service users, such as individuals, companies, or nongovernmental organizations, or from third parties, i.e., government-financed programs (Wunder et al. 2008). In terms of the implications that these have in land use, the literature distinguishes between two broad categories of land-diversion programs: those in which lands are diverted from agriculture or forestry or other

\footnotetext{
${ }^{1}$ United Nations University Institute of Advanced Studies (UNU-IAS), ${ }^{2}$ Department of Geographical Sciences, University of Maryland, College Park,

${ }^{3}$ Sustainability Research Institute, School of Earth and Environment, University of Leeds
} 
such extractive uses to other uses and those in which agricultural production activities are modified to achieve environmental objectives, as in the case of working-land programs (Zilberman et al. 2008). Another categorization of PES focuses on results delivered by such systems. The monitoring of these results has been based either on inputs that facilitate the service provision or on the indicators, i.e., outputs, as identified for the service itself (Zilberman et al. 2008, Zabel and Roe 2009). PES can also be distinguished in payments per land units, payments per service provided, and payments based on avoided costs to restore the ES in question. However, frequently, PES schemes do not pay directly for quantified environmental services, but instead for the land uses or inputs that provide these services by proxy (Wunder 2007, Quintero et al. 2009).

The concept of paying for the provision of ESs is not entirely new; there are well-established precursors such as debt for nature swaps and conservation easements. Agri-environmental policies in the United States and the European Union (EU) have historically promoted PES programs that aimed to reduce the negative externalities arising from agricultural production while providing public subsidies to farmers (Baylis et al. 2008). In developing countries, many PES programs, especially in poorer countries, bring together farmers and international aid agencies seeking a double dividend, i.e., the provision of ESs alongside poverty alleviation. Subsequently, these agencies have increasingly considered using PES programs as a way of meeting social and environmental objectives (Bulte et al. 2008). However, criticism remains strong regarding the ability of PES to create such double wins, for example, because of the limited scope of the services paid for (Redford and Adams 2009) or because PES might even cause the opposite of what was intended (Vatn 2010). At least in theory, PES programs have the potential to make contributions to natural resource management and to sustaining rural livelihoods.

With a similar thematic orientation, the PPP has been part of the environmental discourse since at least the 1950s and, in particular, has been promoted by the Organisation for Economic Co-Operation and Development (OECD) and individual member states since the 1970s (OECD 1972, Førsund 1975). The PPP was understood as a cost-allocation principle according to which the polluter should bear the expenses of carrying out pollution prevention and control measures as decided by public authorities to protect the environment (Førsund 1975), and it was also applied, based on its definition, to cases in which environmental damage occurred. The interpretation and the implementation of the PPP in industrialized countries have also been extensively discussed in relation to agricultural activities and the effects of these on the environment (e.g., Baldock 1992, Seymour et al. 1992).
In what are now diverse and fast-changing rural environments, there is increasingly a need for ES management regimes that take multiple stakeholder views into consideration, e.g., the European Water Framework Directive and the Aarhus Convention. A number of these stakeholders have been alternatively described as property-rights holders because of the rights that each stakeholder has to different ESs (Schlager and Ostrom 1992, Ostrom 2000). Schlager and Ostrom (1992) discuss these rights by beginning with an analysis of the distribution of both rights and costs. However, they also emphasize throughout that "all rights have complementary duties and that to possess a right implies that someone else will have a commensurate duty to observe this right" (Schlager and Ostrom 1992:250). Our aim is to determine if there has in fact been a paradigm shift from the PPP toward the more precautionary, but often insufficiently monitored, PES approach (Pattanayak et al. 2010), whereby the providers of ESs get financial incentives for these services, i.e., following the provider-gets principle (Hanley et al. 1998, Hodge 2000). We compare PES with the PPP in situations where legal frameworks are missing, badly formulated, or badly enforced to provide insights into their differing outcomes. Finally, we address four additional critical issues that PES programs are facing in their implementation. They concern the necessary coexistence of PES with basic rights and legal obligations that sit alongside diverse motivations and sometimes inappropriate claims of ES providers.

\section{DISTRIBUTION OF RIGHTS AND DUTIES, COSTS AND BENEFITS}

\section{Efficient allocation and PES}

Importantly, the distribution of rights, and associated duties, and costs is a central but frequently overlooked aspect of PES. By looking closer at the work of Coase (1960), it can be shown that PES programs focus on the economically efficient allocation of resources. Coase $(1960,1987)$ argued that transaction costs, such as negotiating, monitoring, and enforcement, constitute an irrevocable element of economic reality and, thus, must be included in economic analysis. However, his work has also been interpreted as suggesting that many of the problems caused by market failure through externalities, including environmental ones, could be overcome by using effective legal structures alongside welldefined and enforceable property rights that would thus encourage voluntary contracts (Coase 1987). These arguments apply most readily to those cases in which transaction costs are low and information is readily available.

This original Coasian approach implied a hierarchy similar to the three-stage approach as suggested by authors such as Daly (1992) and Costanza et al. (1997), namely, the following: (1) establishing an ecologically sustainable scale; (2) establishing a socially fair and just distribution of resources using systems of property rights and transfers; and (3) once scale and 
distribution issues are resolved, the application of a marketbased mechanism to reallocate resources from an economic efficiency perspective. The similarity between Coase and Costanza et al. concerns in particular the first and second stages, which are focused on establishing scales that are both ecologically effective as well as fair and just in terms of their distribution.

However, Coase's expressed opinion has been popularized somewhat differently in making the argument that if transaction costs do not exist or are smaller than the resulting benefits, then no regulation beyond the initial distribution of property rights is necessary, with the distribution of appropriate property rights considered sufficient and achievable through negotiation. This is how the Coase theorem is often described, despite the fact that Coase (1987) believed that his conclusions were being misinterpreted. However, user-financed PES programs that are negotiated are considered in accordance with the Coase theorem (Pagiola et al. 2008). Other authors have referred to these PES programs as "selforganized" (Perrot-Maître and Davis 2001) or "private" (Wunder 2005). Engel et al. (2008) have stated that userfinanced PES programs may be more efficient than those that are government financed. However, these same authors also concede that "there are instances where government-financed programs may be the only option" (Engel et al. 2008:667). Other conditions for a Coasian solution include clearly defined property rights that are enforced with low transaction costs (Pagiola and Platais 2007). When all of these preconditions have been met, an efficient or Pareto optimal allocation is said to have occurred through negotiation and market transaction regardless of who initially owned the property rights (Pagiola and Platais 2007). It should be noted, however, that from this theoretical vantage point, PES did not initially consider the socially fair distribution of property rights. PES programs appear to focus instead simply on a legally sound definition of those rights that should be allocated through the market. Moreover, even less focus seems to have been given toward legally effective structures that establish an ecologically sustainable scale at the outset. Thus, the relationship between this allocation approach and the PPP requires further discussion.

\section{Efficient allocation and the PPP}

To date, opinion still varies among authors (Glazyrina et al. 2006, Fischhendler 2007, Pannell 2008) about the choice of the PPP and the associated cost allocations in comparison with other principles, such as the beneficiary-pays or provider-gets principles (Hanley et al. 1998, Hodge 2000). However, there appear to be no major differences between the beneficiarypays principle and the provider-gets principle when, according to Pannell (2008), the general public besides individuals is also the beneficiary. Under the PPP, where property rights are assigned to consumers of environmental quality, and when the polluter pays enough, polluters can more than compensate the consumers at current market prices, with both said to be "better off." One example of this would be a polluting company that pays neighbors more than the market price for their property to get them to move somewhere else. This can be seen as a similarly narrow project-by-project and market-based view such as the perspective that predominates within PES (Norgaard 2010, Vatn 2010). Thus, overall outcomes may or may not be within ecological limits because these were not part of the overall design. These limits are also not achievable through individual negotiations because the focus of individuals and their respective goals are based on their financial interests and existing distribution of resources, money, and rights. This is important because both of the approaches, PES and the PPP, seem to be focused more on individually driven project-by-project efficiency rather than ecologically sustainable scales or the socially fair distribution of rights, at least in the sense of Costanza et al. (1997) and Daly (1992).

\section{Ecologically sustainable scale and inherent qualities of ecosystems}

The concept of ecological sustainability is concentrated on an ecologically sustainable scale of throughput of resources and energy in socioeconomic systems (Boulding 1966, Daly 1992, Mauerhofer 2008). Ecological sustainability, therefore, deals with sustaining environmental limits and is closely related to critical natural capital (CNC; Ekins et al. 2003, Mauerhofer 2008). Farley (2008) noted that CNC generates benefits that are essential to human welfare with few, if any, substitutes. If, as the ES framework suggests, sustainability is ultimately dependent on the ESs provided by natural capital, then environmental managers must maintain viable stocks of natural capital that maintain viable ESs (Hubacek et al. 2009). Only when conservation needs are met should the remaining ecosystem structure be available to supply and demand and the price mechanism: "Thus conservation needs should become the determinants of price and not price determined" (Farley 2008:1406). Therefore, conservation science helps to define ecological limits (Daly 1992). Where the definitions of such limits are not possible, then at least a safe minimum standard should be applied (Ciriacy-Wantrup 1952), with allocation of resources taking place within these boundaries (Mauerhofer 2008). To date, the human use of environmental resources already exceeds several environmental boundaries (Rockström et al. 2009). This existing overconsumption must therefore be taken into serious consideration when defining PES schemes or even when deciding to grant a pollution permit based on the PPP.

Even within these boundaries, price setting under PES schemes or the PPP is very difficult to achieve and bound to miss important factors, such as interdependencies, complex causal interactions, and inherent qualities of biodiversity including ecosystem functions. To date, the clear focus of PES as well as of the PPP has not concentrated on these qualities 
but on economically efficient allocation. Even in the case of the widely cited example of an early PES scheme in Costa Rica, its causal contribution in stopping or reducing further deforestation and restoring an ecologically sustainable scale remains far from proven (Sánchez-Azofeifa et al. 2007, Daniels et al. 2010). Price setting through mainstream marginal valuation has been heavily criticized (e.g., O'Neill and Spash 2000), and as an alternative, deliberative methods have been called for (Spash 2008). This comes alongside the criticism that economic decision makers have until recent decades largely ignored the nonmarket benefits provided by critical natural capital (Farley 2008). Redford and Adams (2009:785-786) refer to the inherent qualities of ecosystems and advocate that "in a world of relentless pursuit of economic logic, there is a risk that economic arguments about services valued by humans will overwrite and outweigh non-economic justifications for conservation," and that "there is a widespread but erroneous assumption that ecosystem services are necessarily benign. Definitions of ecosystem services cite positive values for human society. Only certain things in nature are therefore regarded as services." Hence, inherent qualities of biodiversity, including ecosystems, or costs of the "burdensome" natural phenomena such as storms or floods are often not included in such ES evaluations. In addition, seemingly nonbenign services to humanity should not be excluded from decision making regarding PES and the PPP because they also have important ecological functions.

\section{Distributional effects}

In addition to conservation goals, both PES and the PPP have been widely discussed in the context of potential and practical actions aimed at a socially fair and just distribution of resources (Coase 1960, Daly 1992, Costanza et al. 1997). Hanley et al. (1998), for example, have pointed out that guiding principles such as the PPP might be viewed as devices reflecting society's view on the fair distribution of income; whereas Fischhendler (2007:287) has highlighted that the "PPP may allow us to use the resource most efficiently, but may also result in an inequitable distribution of the cost burden." Similar to this opinion, other diverging views with regard to distributional aspects of PES also occur. Thus, there are frequent arguments that PES should also aim for social justice and poverty reduction (Franco-Maass et al. 2008), whereas others maintain that the prime focus of PES should remain on the environment rather than on poverty reduction (Bulte et al. 2008, Wunder 2008, Wunder and Albán 2008, Zilberman et al. 2008). According to the latter view, poverty reduction can be a positive by-product of environmental goals. Examples of this can be seen in two PES programs in Ecuador, namely, the Pimampiro municipal watershed-protection scheme and the PROFAFOR carbon-sequestration program (Wunder and Albán 2008). Both were relatively effective in terms of their environmental objectives and were seen to have improved the welfare of PES recipients, mostly through higher incomes, although neither scheme had targeted poverty alleviation or had this as an additional objective (Wunder and Albán 2008). However, this raises ethical questions because it can involve utilizing the advantage of the so-called lower cost of conservation found in poorer countries where local stakeholders are only compensated at their current poverty level (Karsenty 2007), leaving them no better off than they were before.

Even within several already long-established PES programs, the redistribution of property rights has not been implemented in an adequate or socially just manner. In Costa Rica's Pagos de Servicios Ambientales PES program, large farms and forest owners have been disproportionately represented among program participants, thereby excluding other members of society (Zbinden and Lee 2005). Similar observations have been made in Chiapas, in Mexico, where the poorest farmers and women were excluded from project design and implementation in the two communities that were involved, in this case, in a project for carbon-sequestration services through forests (Esteve et al. 2007). Subsequently, there is a growing awareness that administrators of projects need to improve their capacity to target payments where they are most needed (Sierra and Russman 2006). The view that poverty reduction should be included in the formation of PES is generally based on an understanding that many ESs do have the character of a public good for which property rights have not been fully defined or allocated. Moreover, destruction of ESs through, for example, deforestation, overgrazing, mining, and overfishing are often carried out by the poor. Following this logic, Franco-Maass et al. (2008) have redefined delivery of ESs as services supplied by the local population for the protection of common goods. According to these authors, "Contributing to local development by paying for natural resource conservation and protection services therefore implies more equity in terms of remuneration because what is being paid for is not only the right to use a private good, but also the work done by the community for the preservation of a common good" (Franco-Maass et al. 2008:24). However, as already briefly mentioned, a number of authors claim that if PES programs attempted to solve both poverty and environmental problems, this might reduce their efficiency in meeting either of the objectives. Thus, those authors argue that PES should focus only on the protection of the ESs for which PES programs were created (Bulte et al. 2008, Wunder 2008, Zilberman et al. 2008), but with the hope that social goals might be achieved as a positive externality.

In summary, there are two directions with regard to PES and social goals. Both recognize the dual nature of PES: One group focuses on environmental aspects, whereas the other argues that despite their primary function to maintain or restore biodiversity, PES programs should be used as instruments for a socially and fair (re)distribution of natural capital. This latter view emphasizes the need for a legal framework to adequately 
integrate these distributional social issues. With this in mind, we discuss the interplay between PPP and PES in a legal framework. By examining three notable examples, it can be seen that inadequacies in the legal framework have reduced the effectiveness of PPP and contributed to the potential of PES.

\section{INTERPLAY OF PES AND THE PPP WITH THE LEGAL FRAMEWORK}

It is widely recognized that having the right legal and institutional structures in place (Coase 1960) constitutes a precondition for properly working PES programs (Pham et al. 2008, Börner et al. 2010, Muradian et al. 2010). Moreover, the rise of PES schemes has been partly driven by perceived and real problems of the PPP in the legal context.

\section{Reasons for applying PES instead of the PPP}

Three reasons for applying PES instead of the PPP can be identified as follows: First, a basic reason is the situation in which no appropriate regulations are in place to indicate any duty on the part of the polluter. Examples of such omissions in the regulatory system include a lack of regulations introducing limits to environmentally destructive natural resource management and, in the case of breaking those limits, a sanction system, including financial sanctions or restrictions to activities. Despite this, however, simple PES systems are still possible even if solely shaped by the distribution of power between the beneficiary and service provider. The second reason for the ineffectiveness of the PPP in environmental protection is found in those situations in which existing regulations are not deemed, especially by the recipients of ESs, to be sufficiently thought through. Even when recipients do not have the political power to change the regulations to a more PPP-oriented system, they may still have the financial power to offer the "polluters" financial incentives via PES to be less environmentally destructive. A third reason for applying PES instead of the PPP is that PES systems also have the benefit of offering incentives for the best environmental practice, especially in situations in which existing, even wellformulated, regulations are not enforced at all. This is typical for those regions that lack sufficient environmental governance and that have high levels of corruption (Engel et al. 2008). Recipients of ESs, if they are financially potent enough, could try in this situation to convince "polluters" by means of PES to reduce or change their environmentally harmful activities.

Thus, it can be seen that even though the three PPP situations described lacked the essential legal framework conditions for their implementation, they did provide a niche for PES to evolve, albeit imperfectly, in their place. In most of the less economically developed and newly industrialized countries, the three situations can be found to partially or completely overlap. In such settings, command-and-control approaches to environmental protection are generally hampered by weak governance, high transaction costs, and information problems associated with the design of effective rules on natural resource use, monitoring, and enforcement (Baland and Platteau 1996). However, even a single change in the distribution of rights and benefits, if fully implemented through a well-balanced command-and-control approach, can foster the provision of ESs and reduce poverty and social conflicts even without complementary PES. This was shown, for example, in Nepal's Community Forest Program (Devkota 2005), which helped overcome insufficient protection enforcement of local authority-owned forests by distributing user rights and monitoring duties to local Community Forest Groups under specified conditions laid down by the government. However, monitoring and enforcement do not necessarily depend on legal provisions but can also be implemented among private stakeholders.

\section{Monitoring and enforcement}

Currently, under the PPP approach, resource users can be fined to provide compensation for damage that they have done to ecosystems and the services they provide. This would be the case when a standard has clearly been exceeded, provided that the polluter who has violated the threshold can be identified. This is only effective if the damage is compensable at all and all the polluters have sufficient money to pay the fines. Therefore, the PPP approach only works if a number of conditions are met, and these include that environmental thresholds are clearly set; when thresholds are exceeded, the polluters are identified; and, where liable, polluters are able to pay, if the payment is enforced at all and is punitive enough to act as a deterrent. If the payments and punishments are not punitive, the polluter will continue to pollute if this is "financially affordable" and the economic benefits of doing so are higher than the fine imposed. In comparison, sanctions consisting of prison sentences are usually more daunting and are therefore applied to more serious offenses. However, from an environmental point of view, the sanction system may still not be effective because the compensation might not be sufficient to protect or restore the quality of the ecosystems in question (see, e.g., Moreno-Mateos et al. 2012).

Regardless of whether the polluter pays or the provider receives, monitoring and enforcement are essential to ensure that conditions are met. In PES situations, program managers require reliable monitoring data to make informed payment decisions, and this includes withholding payments from landowners who do not meet the agreed conservation objectives (Honey-Rosés et al. 2009). If the provision of this is not secured by a contract covering the PES, then the provisions of an enforceable legal framework could also adequately cover this. Without this information, PES programs have frequently been found to overpay noncompliant participants (Honey-Rosés et al. 2009). For example, Goldman et al. (2008) assessed 34 ES projects and 26 traditional biodiversity (BD) projects and found that 
monitoring of conservation outcomes had been so infrequent that it was impossible to assess the effectiveness of either of the ES or BD approaches. In addition, current PES schemes face a number of challenges, namely, difficulties evaluating opportunity costs and ES delivery, high transaction costs, and further difficulties in ensuring conditionality (Ghazoul et al. 2009, Quintero et al. 2009, Zabel and Roe 2009). In another example, in Costa Rica, since the late 1990s, payments have been given to private forest owners in recognition of the ESs their land provides. However, because PES programs were distributed broadly across ecological and socioeconomic gradients, it was found that between 1997 and 2000 deforestation was not significantly reduced in those areas where landowners had received the payments (SánchezAzofeifa et al. 2007). A part of this is the importance of monitoring and enforcement, which is particularly relevant if the conditions have not been fulfilled and the PES already paid then need to be reclaimed. The problem of proving the causality of land management and associated effects on ES delivery also remains. A major impediment to monitoring this is the fact that the link between action and outcome is frequently difficult to make in that a change in provision could be caused by a change in biophysical factors, e.g., precipitation, temperature, and other factors that may be beyond the reach of the land manager.

PES schemes have also been frequently introduced in situations where the PPP principle was thought to address certain damage but was not found to be effective for several reasons, including those related to a lack of monitoring and enforcement, encouraging a paradigm shift from the PPP to the more precautionary PES approach (Bulte et al. 2008). A higher level of precaution is achieved when PES programs are introduced to prevent harm to ecosystems and the services they provide. Moreover, these situations of PES introduction are often especially dependent on an effective legal framework ensuring monitoring and enforcement, which remains crucial for maintaining ecological sustainability.

\section{Restoration, PES, and the PPP}

The role of sanctions and related, potentially insufficient, compensation for the protection or restoration of ecosystem quality has already been briefly discussed. Moreover, in some instances, farmers who had destroyed primary forests were given PES to provide to the beneficiary ESs from the existing land use based on restoration toward a secondary land cover. In the case of Bragantina, in the southeastern Brazilian Amazon, only such "second-order PES" were possible because the primary forest ecosystem functions had already been destroyed (Börner et al. 2007). Hence, polluters received, after the first short-term benefit from the destruction of the forest, PES from beneficiaries to prevent them from doing even more damage (Vatn 2010) instead of asking them to pay compensation as required under the PPP. It is here that PES actually contradicts the PPP in the case that the prior destruction of the primary forest is illegal. In practice, most restorations and attempts to supply lost services through other species or ecosystem components have turned out to be expensive failures (Ehrlich and Mooney 1983). However, recently, several attempts have been made to use PES for restoration purposes (Sierra and Russman 2006, Gutman 2007, Blignaut et al. 2008, Aronson et al. 2010). Under current legislative systems in the EU, PES landholders have no longterm obligation to let land revert to natural ecosystems (Mauerhofer 2010). If payments were provided for restoration, this could at least provide incentives for landholders to restore natural habitats (Sierra and Russman 2006).

\section{Substantive legal differences between PES and the PPP}

Based on the three reasons described, the substantial difference between a payment by the polluter (PPP) and the receipt of PES by the provider is that in the PPP, the legal framework constitutes an initial necessity because it states the duty for the polluter to pay. Another substantial difference between a payment by the polluter (PPP) and payment received by the provider (PES) is that for the former, the threshold condition as noted previously needs to be met, whereas the PES approach does not necessarily need to fulfill such a condition, e.g., voluntary set-aside schemes in farming. Therefore, their outcome in terms of conditionality still remains uncertain unless proof can be provided of an environmental result, a threshold kept, or a particular behavior aiming at a beneficial result (Quintero et al. 2009, Zabel and Roe 2009). Importantly, the deterring effect of financial fines and other sanctions can contribute to the success of the PPP through prevention of damage to ESs. However, a limitation is that polluters can decide to pollute in any case if they can afford to pay the fine in situations in which this is the only negative sanction and no prison sentence is threatening. The PES approach, on the other hand, uses the precautionary principle to conditionally bind a potential polluter to a certain constructive behavior or desired outcome through additional incentives toward building environmental awareness.

At present, PES schemes continue to emerge, partly driven by an increasing focus on precautionary policies fostered by recognition of human rights related to both well-being and the environment. The emergence of PES has been enhanced by the fact that central government policies show shortcomings in preventively implementing the PPP. Examples of these shortcomings include a lack of effective command-andcontrol instruments, a lack of public recognition of the importance of ESs, and the belief in the supremacy of marketbased approaches. It is, however, important to go beyond discussing the legal problems and focus on the four critical issues in relation to the implementation of PES in practice. 


\section{CRITICAL ISSUES FOR THE IMPLEMENTATION OF PES}

We have analyzed the differences between PES and PPP, and the interplay between legal contexts and the operationalization of PES and the PPP. Three situations in particular have been assessed: (1) if no regulations were in place, (2) if existing ones were deemed to be insufficiently formulated, and (3) where sufficient regulations were not enforced. However, even where none of these situations occur, other critical issues still remain with PES, and these can be summarized as follows: (1) the general necessity for PES to coexist with basic rights and legal obligations; (2) the inappropriate, i.e., lexicographic, claims of an ES provider; (3) the inappropriate claims for potential damages; and (4) the relationship of PES with the intrinsic motivation of service providers.

PES in coexistence with basic rights and legal obligations The issue of basic rights is represented by the simple question of whether society has the basic right to the natural capital of clean air and clean water or whether it should have to pay for these as it does for any other good or service? At least two critical issues are inherent in this question, but because they have been extensively discussed by other authors, they need only be briefly mentioned. The first issue relates to the extent of basic human rights in the sense of needs, but not wants, regarding the consumption of natural resources (World Commission on Environment and Development 1987, Alkire 2002, Guha 2006). The other concerns the number of humans that the world can sustain (Ehrlich et al. 1989, Ehrlich and Ehrlich 1990). Patterns of consumption and human settlement are both reciprocally interrelated, and crucial trade-offs have become indispensable (see, e.g., Tisdell 2005, Coleby et al. 2012). As discussed earlier, the introduction of PES was partly driven by an increasing focus on preventive policies fostered by recognition of human rights in managing both health and the environment. This is likely to continue because the human rights in property and ownership continue to play a dominant role in PES schemes. The main question is whether all ESs that provide for basic human needs, as well as others such as life-supporting ESs, should be paid for by the people who need them or whether they are a basic right. Usually, however, legal norms address the questions of basic human rights on a constitutional level, providing obligations to fulfill these rights by states or other public or private stakeholders.

In comparison, issues of other obligations that PES have to coexist with are usually those legal obligations mandated below the constitutional level of human rights. Currently, PES programs often operate in contexts in which various command-and-control regulations already exist (Engel et al. 2008), whereby many PES programs pay for forest conservation in countries where deforestation is already legally prohibited. In these situations, the money is best used in contributing to enforcement of existing laws rather than solely paying PES for compliance. Otherwise, the PES system can encourage noncompliance with the legal framework and undermine its implementation. Thus, financial sanctions in that framework would need to be increased to "compete" with PES. This will in fact be necessary to prevent politically unwise or perverse incentives that are difficult to remove once local communities come to depend on them. Complementary applications of financial conservation instruments, whether as voluntary or mandatory instruments, can also be useful where the PES can "be thought of as providing the carrot that makes the stick of PPP regulations more palatable" (Engel et al. 2008:669).

\section{Inappropriate lexicographic claims of an ES provider}

Inappropriate lexicographic claims refer to specific situations in which providers of ESs raise inappropriate claims for PES, knowing that the ESs are needed. This situation occurs, for example, in nature conservation programs where a national authority is obliged under EU regulations to conserve sites for certain species and habitat types (Mauerhofer 2010). This duty can even be enforced by the EU against an EU member state by means of court ruling, such as the European Court of Justice. For such cases, the possibility for expropriation of land exists in many national legal frameworks, with or without appropriate financial compensation as decided by external adjudicators. Nevertheless, a national or private authority may, apart from its lexicographic claims, often not have the financial resources to offer appropriate financial compensation. This can even be valid within the international community. For example, the international community did not pay out in the Yasuní Ishpingo Tambococha Tiputini case (Rival 2010) when the Ecuadorian government claimed compensation for half of the prospective oil revenues considered to be obtainable from exploitation of the Ecuadorian Yasuní territory. This claim was made as a price for leaving the area untouched to provide ESs to Ecuador and beyond.

\section{Inappropriate claims for potential damages}

The previous point is closely related to the third issue in highlighting the focus of PES on potential damages. It is of crucial importance to distinguish payments to the provider for a proximate behavior, i.e., assumed to lead to ES outcomes, for the provision of ESs, i.e., in the sense of "conditionality," and for incurred opportunity costs. This is of particular significance within nature conservation where compensations related to site designation often include compensation for opportunity costs to an extent that could make ESs unaffordable because an owner of the ESs could claim excessive opportunity costs and thus even ask for exorbitant intrinsic values from the activity that would diminish the ESs in question. Coleby et al. (2009) show this in an example of compensation payments requested by some rural property 
owners in the United Kingdom adjacent to wind farms. This has been the case in a number of renewable energy developments in the United Kingdom and elsewhere when disputes between stakeholders are more often based on aesthetics rather than ecology.

However, excessive claims do not have to be accepted in any way when regulatory limits are provided for by a sound legal framework in which expropriation is used as a means of enforcing conservation targets. Even weakly enforced regulations are able to reduce expected gains from noncompliance, and in doing so complement PES programs by increasing incentives to participate, and reduce requests for payment (Wunder and Albán 2008). This is of overall importance, especially if, and this is often the case, opportunity costs are larger than the PES to be paid (Karsenty 2007, Kosoy et al. 2007). One example of a method used to clarify opportunity costs can be found in Indonesia (Jack et al. 2009), where a PES program on mitigation of soil erosion from coffee plantations used an auction-based approach to reveal private information on the price of the PES; however, whether this approach is really adequate requires further research. For example, compared with the maximum result provided by an auction, some contingent valuation analyses undertaken in Ecuador and Guatemala on potential PES have found that the minimum compensation demanded by rural households was far from uniform (Southgate et al. 2010). The opportunity costs depended in particular on individual strategies for raising incomes and dealing with local risks (Southgate et al. 2010).

These three critical issues indicate that there is a clear need for an underlying legal framework predetermining an ecologically sustainable scale alongside a socially just distribution. This has been shown in countries like Brazil where PES systems could not substitute for legal measures (Börner et al. 2010). In Brazil, PES programs depended on legislation for basic governance systems to secure effective rights of exclusion, which land managers needed to become reliable service providers. Similarly, economic incentives for tropical forest management and conservation have subsequently revealed the evolution from market incentives to increasing emphasis on governance and regulatory incentives (Richards 2007). These included regulations to create PES markets, identify the value of public goods, and secure property rights (Richards 2007).

\section{PES, local empowerment, and intrinsic motivation}

Other examples of existing PES systems continue to indicate a need for more local empowerment as well as institutional and organizational improvements. In Cameroon, the implementation of Clean Development Mechanism projects within two community forest examples showed that community capacity was generally insufficient for meaningful participation and implementation of PES projects (Minang et al. 2007). Similarly, in Mexico, marketing forest carbon was hampered by a lack of organizational capacity in government and civil society, which was compounded by uncertainties in international policies and between existing common property institutions in rural areas (Corbera and Brown 2008). Such a lack of capacity has also been found in rural Cambodia where three PES programs were thought to be more sustainable if they empowered local institutions (Clements et al. 2010). These authors emphasize the need for PES programs to reinforce intrinsic motivations. This more altruistic aim can, of course, somehow contradict a PES program with its focus on economic incentives.

\section{CONCLUSIONS}

Ecosystem services represent a paradigm shift in environmental policy from the perceived failure, or dislike, of the top-down command-and-control policies of the 1960s to 1980s. Subsequently, alongside the various subsidy schemes, the emergence of more market-driven approaches can be observed. We have entered a phase in which markets for ESs are being created with the aim of encouraging owners of land or property rights to provide ESs by being paid for them. The earlier doctrine of the PPP has increasingly been replaced by "provider-gets" principles, in which it is often the public that indirectly pays for environmental benefits. For example, the public pays either through tax reductions or through higher product prices if the PES did not pay partly or fully for the ES benefits in question. Alternatively, these costs incurred by the company, e.g., a water company paying substantial amounts of money to farmers for less intensive farming practices, could lead to a reduction of shareholder value and could thus constitute a cost. In this situation, a redistribution of property rights takes place from the public to the provider of the ES.

More recently, the debate has widened to question the market philosophy of PES based on notions of legitimacy, justice, and empowerment. Therefore, it is important to look not only at how property-rights owners can be given incentive to provide ESs but also at how in paying for such services the list of property rights has been extended from ownership of natural resources to vital public goods.

In response to this, a process is needed that attempts to integrate these concerns more fully, one that considers the social, economic, and political-cultural contexts of ESs and the distributional effects that PES can cause. Different stakeholders are likely to value ESs in various ways, which may vary in different contexts, and thus there is a need to emphasize the importance of stakeholder perceptions (Coleby et al. 2009) and their property rights, as well as identify institutions for the management of ESs. This, in turn, highlights the need for participatory approaches and greater decentralization of control over ES management.

From the practice of the PPP and PES, it can be seen that a paradigm shift has taken place from the PPP toward the more precautionary, but also often more poorly monitored and 
enforced, and mainly allocation-focused PES approach in which providers receive money in exchange for ESs. The decision to move from the PPP to PES is, in particular in less economically developed countries, driven by the lower feasibility of practical enforcement of the PPP. This has been because of the political influence of polluters, the absence of polluters in the areas polluted by them, and a lack of causal evidence needed to stop them. The transition from PPP to PES has also been more influenced in this way by notions of interand intragenerational equity between small-scale potential polluters in less economically developed countries and existing large-scale polluters in more economically developed countries; indeed the authors owe this thought to one of the anonymous reviewers of the journal. In this sense, a stronger focus of PES in the future toward more socially fair redistribution can be considered an expression of the principle of common but differentiated responsibility (e.g., Mauerhofer 2008).

PES could satisfy both the goals of conservation and poverty alleviation, and now this dual objective in PES is growing both in popularity and importance. Therefore, PES, similar to the PPP, will require strengthened formal governance, including a legal framework with effective enforcement and monitoring. In addition, less formalized governance measures that deal with building capacity and raising awareness need to be implemented on appropriate geographic scales. In this way, the ESs paid for are then provided, which means that PES program objectives can be met in terms of conservation of natural resources and biodiversity and can empower the community as a stakeholder. Moreover, a solely voluntary approach to PES will not be enough to conserve ESs that are public goods because of the critical issues of basic rights to clean water and more, differing lexicographic claims and inappropriate opportunity costs. Finally, it is because of these obstacles that PES should not be seen as the sole instrument to ensure conservation of ESs, but rather as a complementary tool to the properly enforced and monitored PPP alongside increased public awareness and stronger intrinsic motivations on behalf of the environment.

Responses to this article can be read online at: http://www.ecologyandsociety.org/issues/responses. php/6025

\section{Acknowledgments:}

The authors are grateful to Christina Prell and three anonymous reviewers for their helpful comments on earlier parts of the paper, as well as Nicholas Ouellette for checking the English.

\section{LITERATURE CITED}

Alkire, S. 2002. Dimensions of human development. World Development 30:181-205.

Aronson, J., J. N. Blignaut, S. J. Milton, D. Le Maitre, K. J. Esler, A. Limouzin, C. Fontaine, M. P. De Wit, W. Mugido, P. Prinsloo, L. Van Der Elst, and N. Lederer. 2010. Are socioeconomic benefits of restoration adequately quantified? A meta-analysis of recent papers (2000-2008) in Restoration Ecology and 12 other scientific journals. Restoration Ecology 18:143-154. http://dx.doi.org/10.1111/j.1526-100X.2009.00638. $\underline{\mathrm{X}}$

Baland, J. M., and J. P. Platteau. 1996. Halting degradation of natural resources: is there a role for rural communities? Clarendon, Oxford, UK.

Baldock, D. 1992. The polluter pays principle and its relevance to agricultural policy in European countries. Sociologia Ruralis 32:49-65. http://dx.doi.org/10.1111/j.1467-9523.1992. tb00918.x

Baylis, K., S. Peplow, G. Rausser, and L. Simon. 2008. Agrienvironmental policies in the EU and United States: a comparison. Ecological Economics 65:753-764. http://dx.doi. org/10.1016/j.ecolecon.2007.07.034

Blignaut, J., J. Aronson, M. Mander, and C. Marais. 2008. Investing in natural capital and economic development: South Africa's Drakensberg Mountains. Ecological Restoration 26:143-150. http://dx.doi.org/10.3368/er.26.2.143

Börner, J., A. Mendoza, and S. A. Vosti. 2007. Ecosystem services, agriculture, and rural poverty in the Eastern Brazilian Amazon: interrelationships and policy prescriptions. Ecological Economics 64:356-373. http://dx.doi.org/10.1016/ j.ecolecon.2007.03.001

Börner, J., S. Wunder, S. Wertz-Kanounnikoff, M. Rügnitz Tito, L. Pereira, and N. Nascimento. 2010. Direct conservation payments in the Brazilian Amazon: scope and equity implications. Ecological Economics 69:1272-1282. http://dx. doi.org/10.1016/j.ecolecon.2009.11.003

Boulding, K. E. 1966. The economics of the coming spaceship Earth. Pages 3-14 in H. Jarrett, editor. Environmental quality in a growing economy. Resources for the Future/Johns Hopkins University Press, Baltimore, Maryland, USA.

Bulte, E. H., L. Lipper, R. Stringer, and D. Zilberman. 2008. Payments for ecosystem services and poverty reduction: concepts, issues, and empirical perspectives. Environment and Development Economics 13:245-254. http://dx.doi.org/10.1017/ $\underline{\mathrm{S} 1355770 \mathrm{X} 08004348}$

Ciriacy-Wantrup, S. V. 1952. Resource conservation: economies and politics. University of California Press, Berkeley, California, USA. 
Clements, T., A. John, K. Nielsen, D. An, S. Tan, and E. J. Milner-Gulland. 2010. Payments for biodiversity conservation in the context of weak institutions: comparison of three programs from Cambodia. Ecological Economics 69:1283-1291. http://dx.doi.org/10.1016/j.ecolecon.2009.11.010

Coase, R. H. 1960. The problem of social cost. Journal of Law and Economics 3:1-44. http://dx.doi.org/10.1086/466560

Coase, R. H. 1987. The firm, the market, the law. University of Chicago Press, Chicago, Illinois, USA. http://dx.doi. org/10.7208/chicago/9780226051208.001.0001

Coleby, A. M., D. R. Miller, and P. A. Aspinall. 2009. Public attitudes and participation in wind turbine development. Journal of Environmental Assessment Policy and Management 11:69-95. http://dx.doi.org/10.1142/

$\underline{\mathrm{S} 1464333209003221}$

Coleby, A. M., D. van der Horst, K. Hubacek, C. Goodier, P. J. Burgess, A. Graves, R. Lord, and D. Howard. 2012. Environmental impact assessment, ecosystems services and the case of energy crops in England. Journal of Environmental Planning and Assessment 55:369-385. http://dx.doi. org/10.1080/09640568.2011.603958

Corbera, E., and K. Brown. 2008. Building institutions to trade ecosystem services: marketing forest carbon in Mexico. World Development 36:1956-1979. http://dx.doi.org/10.1016/j. worlddev.2007.09.010

Costanza, R., H. E. Daly, R. Goodland, and R. B. Norgaard. 1997. An introduction to ecological economics. St. Lucie, Boca Raton, Florida, USA.

Daily, G. C., T. Söderqvist, S. Aniyar, K. Arrow, P. Dasgupta, P. R. Ehrlich, C. Folke, A. Jansson, B.-O. Jansson, N. Kautsky, S. Levin, J. Lubchenco, K.-G. Mäler, D. Simpson, D. Starrett, D. Tilman, and B. Walker. 2000. The value of nature and the nature of value. Science 289:395-396. http://dx.doi. org/10.1126/science.289.5478.395

Daly, H. E. 1992. Allocation, distribution, and scale: towards an economics that is efficient, just, and sustainable. Ecological Economics 6:185-193. http://dx.doi.org/10.1016/0921-8009 (92)90024-M

Daniels, A. E., K. Bagstad, V. Esposito, A. Moulaert, and C. M. Rodriguez. 2010. Understanding the impacts of Costa Rica's PES: are we asking the right questions? Ecological Economics 69:2116-2126. http://dx.doi.org/10.1016/j. ecolecon.2010.06.011

Devkota, S. R. 2005. Is strong sustainability operational? An example from Nepal. Sustainable Development 13:297-310. http://dx.doi.org/10.1002/sd.255

Ehrlich, P. R., G. C. Daily, A. H. Ehrlich, P. Matson, and P. Vitousek. 1989. Global change and carrying capacity: implications for life on Earth. Stanford Institute for Population and Resource Studies, Stanford, California, USA.

Ehrlich, P. R., and A. H. Ehrlich. 1990. The population explosion. Simon and Schuster, New York, New York, USA.

Ehrlich, P. R, and H. A. Mooney. 1983. Extinction, substitution, and ecosystem services. BioScience 33:248-254. http://dx.doi.org/10.2307/1309037

Ekins, P., C. Folke, and R. De Groot. 2003. Identifying critical natural capital. Ecological Economics 44:159-163. http://dx. doi.org/10.1016/S0921-8009(02)00271-9

Engel, S., S. Pagiola, and S. Wunder. 2008. Designing payments for environmental services in theory and practice: an overview of the issues. Ecological Economics 65:663-674. http://dx.doi.org/10.1016/j.ecolecon.2008.03.011

Esteve, C., K. Brown, and W. N. Adger. 2007. The equity and legitimacy of markets for ecosystem services. Development and Change 38:587-613. http://dx.doi.org/10.1111/ j.1467-7660.2007.00425.x

Farley, J. 2008. The role of prices in conserving critical natural capital. Conservation Biology 22:1399-1408. http://dx.doi. org/10.1111/j.1523-1739.2008.01090.x

Fischhendler, I. 2007. Escaping the "polluter pays" trap: financing wastewater treatment on the Tijuana-San Diego border. Ecological Economics 63:485-498. http://dx.doi. org/10.1016/j.ecolecon.2006.12.012

Førsund, F. R. 1975. The polluter pays principle and transitional period measures in a dynamic setting. Swedish Journal of Economics 77:56-68. http://dx.doi.org/10.2307/3439327

Franco-Maass, S., G. Nava-Bernal, A. Endara-Agramont, and C. González-Esquivel. 2008. Payments for environmental services: an alternative for sustainable rural development? The case of a national park in the central highlands of Mexico. Mountain Research and Development 28:23-25. http://dx.doi. org/10.1659/mrd.0971

Ghazoul, J., C. Garcia, and C. G. Kushalappa. 2009. Landscape labelling: a concept for next-generation payment for ecosystem service schemes. Forest Ecology and Management 258:1889-1895. http://dx.doi.org/10.1016/j. foreco.2009.01.038

Glazyrina, I., V. Glazyrin, and S. Vinnichenko. 2006. The polluter pays principle and potential conflicts in society. Ecological Economics 59:324-330. http://dx.doi.org/10.1016/ j.ecolecon.2005.10.020

Gobbi, J. A. 2000. Is biodiversity-friendly coffee financially viable? An analysis of five different coffee production systems in western El Salvador. Ecological Economics 33:267-281. http://dx.doi.org/10.1016/S0921-8009(99)00147-0 
Goldman, R. L., H. Tallis, P. Kareiva, and G. C. Daily. 2008. Field evidence that ecosystem service projects support biodiversity and diversify options. Proceedings of the National Academy of Sciences of the United States of America 105:9445-9448. http://dx.doi.org/10.1073/pnas.0800208105

Guha, A. 2006. How much should a person consume? University of California Press, Berkeley, California, USA.

Gutman, P. 2007. Ecosystem services: foundations for a new rural-urban compact. Ecological Economics 62:383-387. http://dx.doi.org/10.1016/j.ecolecon.2007.02.027

Hanley, N., H. Kirkpatrick, I. Simpson, and D. Oglethorpe. 1998. Principles for the provision of public goods from agriculture: modeling moorland conservation in Scotland. Land Economics 74:102-113. http://dx.doi.org/10.2307/3147216

Hodge, I. 2000. Agri-environmental relationships and the choice of policy mechanism. World Economy 23:257-273. http://dx.doi.org/10.1111/1467-9701.00271

Honey-Rosés, J., J. López-García, E. Rendón-Salinas, A. Peralta-Higuera, and C. Galindo-Leal. 2009. To pay or not to pay? Monitoring performance and enforcing conditionality when paying for forest conservation in Mexico. Environmental Conservation 36:120-128. http://dx.doi. org/10.1017/S0376892909990063

Hubacek, K., N. Beharry, A. Bonn, T. Burt, J. Holden, F. Ravera, M. Reed, L. Stringer, and D. Tarrasón. 2009. Ecosystem services in dynamic and contested landscapes: the case of UK uplands. Pages 167-188 in M. Winter and M. Lobley, editors. What is land for? The food, fuel and climate change debate. Earthscan, London, UK.

Jack, B. K., B. Leimona, and P. J. Ferraro. 2009. A revealed preference approach to estimating supply curves for ecosystem services: use of auctions to set payments for soil erosion control in Indonesia. Conservation Biology 23:359-367. http://dx.doi.org/10.1111/j.1523-1739.2008.01086. $\underline{\mathrm{x}}$

Karsenty, A. 2007. Questioning rent for development swaps: new market-based instruments for biodiversity acquisition and the land-use issue in tropical countries. International Forestry Review 9:503-513. http://dx.doi.org/10.1505/ifor.9.1.503

Kinzig, A. P., C. Perrings, F. S. Chapin III, S. Polasky, V. K. Smith, D. Tilman, and B. L. Turner II. 2011. Paying for ecosystem services—promise and peril. Science 334:603-604. http://dx.doi.org/10.1126/science.1210297

Kosoy, N., M. Martinez-Tuna, R. Muradian, and J. MartinezAlier. 2007. Payments for environmental services in watersheds: insights from a comparative study of three cases in Central America. Ecological Economics 61:446-455. http:// dx.doi.org/10.1016/j.ecolecon.2006.03.016
Mauerhofer, V. 2008. 3-D sustainability: an approach for priority setting in situation of conflicting interests towards a sustainable development. Ecological Economics 63:496-506. http://dx.doi.org/10.1016/j.ecolecon.2007.09.011

Mauerhofer, V. 2010. Missing links: how individual's can contribute to reserve policy enforcement on the example of the European Union. Biodiversity and Conservation 19:601-618. http://dx.doi.org/10.1007/s10531-009-9737-9

Minang, P. A., M. K. McCall, and H. Th. A. Bressers. 2007. Community capacity for implementing clean development mechanism projects within community forests in Cameroon. Environmental Management 39:615-630. http://dx.doi. org/10.1007/s00267-005-0275-2

Moreno-Mateos, D., M. E. Power, F. A. Comín, and R. Yockteng. 2012. Structural and functional loss in restored wetland ecosystems. PLOS Biology 10(1):e1001247. http:// dx.doi.org/10.1371/journal.pbio.1001247

Muradian, R., E. Corbera, U. Pascual, N. Kosoy, and P. H. May. 2010. Reconciling theory and practice: an alternative conceptual framework for understanding payments for environmental services. Ecological Economics 69:1202-1208. http://dx.doi.org/10.1016/j.ecolecon.2009.11.006

Norgaard, R. B. 2010. Ecosystem services: from eye-opening metaphor to complexity blinder. Ecological Economics 69:1219-1227. http://dx.doi.org/10.1016/j.ecolecon.2009.11.009

O'Neill, J., and C. L. Spash. 2000. Conceptions of value in environmental decision-making. Environmental Values 9:521-536. http://dx.doi.org/10.3197/096327100129342191

Organisation for Economic Co-Operation and Development (OECD). 1972. Recommendation of the Council on guiding principles concerning international economic aspects of environmental policies. C(72)128. OECD, Paris, France.

Ostrom, E. 2000. Private and common property rights. Pages 332-379 in B. Bouckaert and G. De Geest, editors. Encyclopedia of law and economics. Volume II, civil law and economics. Edward Elgar, Cheltenham, UK.

Pagiola, S., P. Agostini, J. Gobbi, C. de Haan, M. Ibrahim, E. Murgueitio, E. Ramírez, M. Rosales, and J. P. Ruíz. 2004. Paying for biodiversity conservation services in agricultural landscapes. Environment Department Paper No. 96. World Bank, Washington, D.C., USA.

Pagiola, S., and G. Platais. 2007. Payments for environmental services: from theory to practice. World Bank, Washington, D.C., USA.

Pagiola, S., A. R. Rios, and A. Arcenas. 2008. Can the poor participate in payments for environmental services? Lessons from the Silvopastoral Project in Nicaragua. Environment and 
Development Economics 13:299-325. http://dx.doi.org/10.1017/ $\underline{\text { S1355770X08004270 }}$

Pannell, D. J. 2008. Public benefits, private benefits, and policy mechanism choice for land-use change for environmental benefits. Land Economics 84(2):225-240.

Pattanayak, S. K., S. Wunder, and P. J. Ferraro. 2010. Show me the money: do payments supply environmental services in developing countries? Review of Environmental Economics and Policy 4:254-274. http://dx.doi.org/10.1093/reep/req006

Perrot-Maître, D., and P. Davis. 2001. Case studies of markets and innovative financing mechanisms for water services from forests. Forest Trends, Washington, D.C., USA.

Pham, T. T., M. H. Hoang, and B. M. Campbell. 2008. Propoor payments for environmental services: challenges for the government and administrative agencies in Vietnam. Public Administration and Development 28:363-373. http://dx.doi. org/10.1002/pad.513

Quintero, M., S. Wunder, and R. D. Estrada. 2009. For services rendered? Modeling hydrology and livelihoods in Andean payments for environmental services schemes. Forest Ecology and Management 258:1871-1880. http://dx.doi.org/10.1016/ j.foreco.2009.04.032

Redford, K. H., and W. M. Adams. 2009. Payment for ecosystem services and the challenge of saving nature. Conservation Biology 23:785-787. http://dx.doi.org/10.1111/ j.1523-1739.2009.01271.x

Richards, M. 2007. Evolving perspectives of the 'difficult economics' of SFM and conservation. International Forestry Review 9:797-804. http://dx.doi.org/10.1505/ifor.9.3.797

Rival, L. 2010. Ecuador's Yasuní-ITT Initiative: the old and new values of petroleum. Ecological Economics 70:358-365. http://dx.doi.org/10.1016/j.ecolecon.2010.09.007

Rockström, J., W. Steffen, K. Noone, Å. Persson, F. S. Chapin III, E. F. Lambin, T. M. Lenton, M. Scheffer, C. Folke, H. J. Schellnhuber, B. Nykvist, C. A. de Wit, T. Hughes, S. van der Leeuw, H. Rodhe, S. Sörlin, P. K. Snyder, R. Costanza, U. Svedin, M. Falkenmark, L. Karlberg, R. W. Corell, V. J. Fabry, J. Hansen, B. Walker, D. Liverman, K. Richardson, P. Crutzen, and J. A. Foley. 2009. A safe operating space for humanity. Nature 461:472-475. http://dx.doi.org/10.1038/461472a

Sánchez-Azofeifa, G. A., A. Pfaff, J. A. Robalino, and J. P. Boomhower. 2007. Costa Rica's payment for environmental services program: intention, implementation, and impact. Conservation Biology 21:1165-1173. http://dx.doi.org/10.1111/ j.1523-1739.2007.00751.x

Schlager, E., and E. Ostrom. 1992. Property-rights regimes and natural resources: a conceptual analysis. Land Economics 68:249-262. http://dx.doi.org/10.2307/3146375
Seymour S., G. Cox, and P. Lowe. 1992. Nitrates in water: the politics of the 'polluter pays principle.' Sociologia Ruralis 32:82-103. http://dx.doi.org/10.1111/j.1467-9523.1992.tb00920. $\underline{x}$

Sierra, R., and E. Russman. 2006. On the efficiency of environmental service payments: a forest conservation assessment in the Osa Peninsula, Costa Rica. Ecological Economics 59:131-141. http://dx.doi.org/10.1016/j. ecolecon.2005.10.010

Southgate, D., T. Haab, J. Lundine, and F. Rodríguez. 2010. Payments for environmental services and rural livelihood strategies in Ecuador and Guatemala. Environment and Development Economics 15:21-37. http://dx.doi.org/10.1017/ $\underline{\mathrm{S} 1355770 \mathrm{X} 09005361}$

Spash, C. L. 2008. How much is that ecosystem in the window? The one with the bio-diverse trail. Environmental Values 17:259-284. http://dx.doi.org/10.3197/096327108X303882

Tisdell, C. A. 2005. Economics of environmental conservation. Second edition. Edward Elgar, Cheltenham, UK.

Turner, R. K., and G. C. Daily. 2008. The ecosystem services framework and natural capital conservation. Environmental and Resource Economics 39:25-35. http://dx.doi.org/10.1007/ s10640-007-9176-6

Vatn, A. 2010. An institutional analysis of payments for environmental services. Ecological Economics 69:1245-1252. http://dx.doi.org/10.1016/j.ecolecon.2009.11.018

World Commission on Environment and Development. 1987. Our common future. Oxford University Press, Oxford, UK.

Wunder, S. 2005. Payments for environmental services: some nuts and bolts. Occasional Paper 42. Center for International Forestry Research, Bogor, Indonesia.

Wunder, S. 2007. The efficiency of payments for environmental services in tropical conservation. Conservation Biology 21:48-58. http://dx.doi.org/10.1111/j.1523-1739.2006.00559. $\underline{\mathrm{X}}$

Wunder, S. 2008. Payments for environmental services and the poor: concepts and preliminary evidence. Environment and Development Economics 13:279-297. http://dx.doi.org/10.1017/ $\underline{\mathrm{S} 1355770 \mathrm{X} 08004282}$

Wunder, S., and M. Albán. 2008. Decentralized payments for environmental services: the cases of Pimampiro and PROFAFOR in Ecuador. Ecological Economics 65:685-698. http://dx.doi.org/10.1016/j.ecolecon.2007.11.004

Wunder, S., S. Engel, and S. Pagiola. 2008. Taking stock: a comparative analysis of payments for environmental services programs in developed and developing countries. Ecological 
Economics 65:834-852. http://dx.doi.org/10.1016/j.

ecolecon.2008.03.010

Zabel, A., and B. E. Roe. 2009. Performance payments for environmental services: lessons from economic theory on the strength of incentives in the presence of performance risk and performance measurement distortion. Institute for Environmental Decisions (IED) Working Paper 7. IED, Zurich, Switzerland. http://dx.doi.org/10.2139/ssrn.1430419

Zbinden, S., and D. R. Lee. 2005. Paying for environmental services: an analysis of participation in Costa Rica's PSA Program. World Development 33:255-272. http://dx.doi. org/10.1016/j.worlddev.2004.07.012

Zilberman, D., L. Lipper, and N. McCarthy. 2008. When could payments for environmental services benefit the poor? Environment and Development Economics 13:255-278. http:// dx.doi.org/10.1017/S1355770X08004294 